B.A.J. 10, III, 679-680 (2004)

\title{
MEMOIR
}

\section{PETER EDWARD MOODY}

Peter Edward Moody was born on 26 August 1918, and was educated at Christ's College, Finchley. He joined the Prudential Assurance as a clerk after leaving school. During the Second World War he was commissioned in the Royal Artillery, serving in France after D-Day. His younger brother, to whom he was very close, died in action as an RAF pilot, and Peter rarely spoke of his own wartime experiences. On demobilisation he returned to the Prudential, qualifying as a Fellow of the Institute of Actuaries in 1947.

He became Deputy Investment Manager of the Prudential in 1960, and joint Chief Investment Officer and Secretary in 1973 - the year of the OPEC oil shock and the onset of the 'fringe bank' crisis, provoked by the collapse of share and property prices. As the City's largest investment institution, with a portfolio of more than $£ 2$ billion, the Prudential was a key participant in the Bank of England's 'lifeboat' scheme, which provided capital to save companies such as Town \& City Properties and United Dominions Trust from impending bankruptcy.

Peter was one of the most powerful investment managers in the City of London during the turbulent stock markets of the 1970s. In December 1974, he formed the view that the stock market, having fallen by more than 70 per cent from its 1972 peak, was at last due for an upswing. He believed that a concerted show of institutional confidence might make the difference, and invited his opposite numbers from Commercial Union, Equity \& Law, Legal \& General, Sun Alliance and London Assurance to lunch at the Prudential's High Holborn headquarters, where they agreed on a $£ 20$ million share-buying operation, which duly turned the FTSE index around from its 20-year low of 143 on 6 January 1975. Within two months the index had doubled.

Peter was a man of quiet determination and charm, who expressed concern or disapproval by no more than a raising of the eyebrows; he commanded respect throughout the City. He had to grapple with difficult investment conditions for the rest of the decade, as well as with a series of hostile interventions by the Labour Government. These included the 1976 Companies Act, which required the disclosure of holdings of five per cent or more in listed companies, whereas previous legislation had set the limit at ten per cent. The Prudential turned out to have declarable holdings in more than 200 companies.

Investment institutions and banks were under constant criticism from the Chancellor of the Exchequer, Denis Healey, and other ministers for their perceived failure to provide capital for industrial development. In response, the Bank of England sponsored the creation of Equity Capital for Industry, a so-called 'equity bank', with Peter Moody as one of its founding directors. ECI eventually attracted the backing of some 350 City institutions, but with the proviso that it should back companies which could not raise money by conventional routes. With such a restricted brief at a time when British entrepreneurship was largely moribund, the venture made little impact.

In 1976 Peter gave evidence to Lord Bullock's committee on 'industrial democracy', which inspired by the German system of supervisory boards - proposed giving shop floor workers the right to elect up to one third of the members of public company boards. He and other witnesses from the City pointed out that such radical measures could lead only to a further period of stock market instability; it came as a relief to the investment community when the proposals eventually ran into the sand.

After his time as Chief Investment Manager of the Prudential, Peter joined the board of the group in 1981, and was Deputy Chairman from 1984 to 1988. He was also a director of the Laird engineering group; of Finance for Industry; of the venture capital group now called 3i; of 
Inmos, a microchip venture sponsored by the National Enterprise Board; and of a number of companies in which the Prudential held significant stakes. He was a member of the Post Office Board and a trustee of the Thalidomide Trust. He was awarded a CBE in 1981.

Peter served as Honarary Secretary of the Institute from 1968 to 1970, as Vice-President from 1972 to 1975, and as President from 1978 to 1980. He was Master of the Worshipful Company of Actuaries from 1988 to 1989.

Peter was a keen golfer, and was captain of the Brookmans Park club in Hertfordshire. In 1945 he married Peggy Causer, who died in 1996. They had a son and a daughter. He died on 12 May 2004, at the age of 85 .

The major part of this memoir appeared first in the Daily Telegraph, on 25 May 2004, and is printed here with the permission of the Daily Telegraph. 